\title{
Gisbertus Voetius (1589-1676): Some perspectives on his influence on developments in the South African Dutch Reformed Church's missiology and mission practice
}

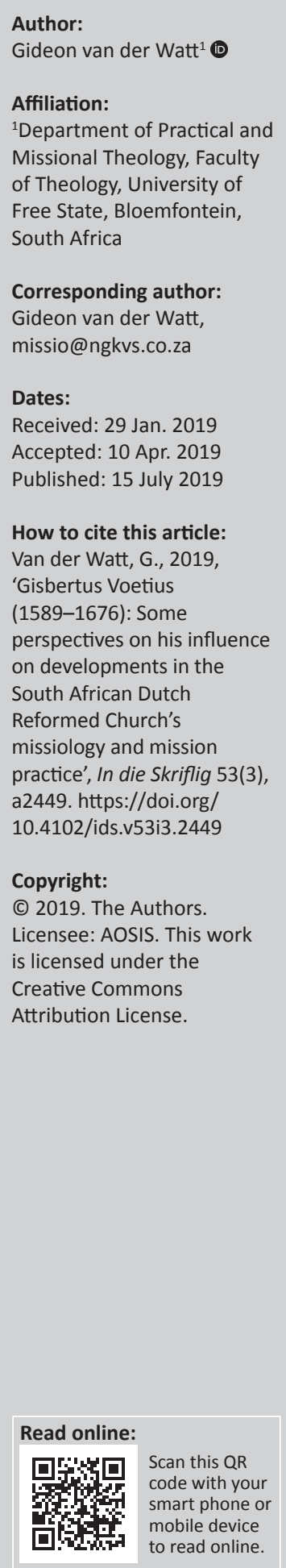

Gisbertus Voetius (1589-1676) played a significant role in the Synod of Dordt 1618-1619. As orthodox Calvinist and leading intellectual in the Dutch Second Reformation, he helped to shape the religious, philosophical and cultural landscape of the 17th century Dutch 'Golden Age'. He was the first Protestant to have developed a comprehensive 'theology of mission'. This article reflects on Voetius' missiology, and specifically its influence on developments in the mission practice and theology in the Dutch Reformed Church in South Africa. The article also enters into a conversation with Voetius from a current South African missional discourse.

Keywords: Voetius; Dordt; Missiology; Second Reformation; Election; Conversion Dutch Reformed Church; South Africa.

\section{Introduction}

In David Bosch's Transforming mission, he describes Voetius as the first Protestant to have developed a comprehensive 'theology of mission' (Bosch 1991:257-258). He concurs with Jongeneel (1991b:78) that, although Voetius is 'hopelessly outdated', he is also surprisingly 'modern' with significant relevance for today. Voetius may rightfully be considered one of the first exponents of the 'modern' concept of missio Dei. His missiology can be characterised as theocentric, even expressly Trinitarian. He founded mission in God's hidden and revealed will (decretum, promissiones and mandatum), that is, in God's predestination and election. The goal of mission is the calling, conversion and salvation of the elect (collectio et salus electorum) from all peoples (universitas Gentium), the planting of the church (collectio et constitution ecclesiae aut ecclesiarum), all to the glory of God's grace (gloria et manfestatio gratiae divinae) (Jongeneel 1991b:56, 68; Van Andel 1912:60ff.). His definition of mission was broader than those in subsequent centuries. He also developed what would today be known as a 'contextual' theology of mission (Jongeneel 1991b:51). As part of the 400th commemoration of the Synod of Dordt (1618-1619), in which Voetius played an active part, this article firstly reflects on Voetius' missiology, and secondly, it specifically focuses on Voetius' influence on developments in the mission practice and theology in the Dutch Reformed Church in South Africa. From a current South African discourse in missiology, it also endeavours to enter into a discussion with Voetius.

\section{Historical background: The life and world of Voetius}

Voetius lived and worked in the Netherlands during the Dutch Golden Age, a period roughly stretching over the 17th century. During this era the Dutch trade, military, science, philosophy and art were among the most acclaimed in the world. The Eighty Year's War with Spain (1568-1648) came to an end and the Republic of Seven United Provinces consolidated their unity and independence. It was an era of material prosperity and cultural flourishing: the United Dutch East India Company (Verenigde Oost-Indische Compagnie, abbreviated to VOC) as well as the West India Company (WIC) dominated trade with foreign countries; Dutch universities were established and excelled; it was the age of Rembrandt van Rijn, Johannes Vermeer, Hugo Grotius, René Descartes, Baruch Spinoza, Christiaan Huygens and Joost van den Vondel. During this century, the Protestant church gained dominance in Dutch society with the Synod of Dordt (1618-1619) - a watershed event (Knegt 2018:263). Gisbertus Voetius, the brilliant scholar, rector of the University of Utrecht, prolific writer, minister and leader of the Dutch Second Reformation (Nadere Reformatie), played a major role in helping to shape this tumultuous and yet enthralling age. 
Voetius was born in Heusden, North-Brabant. He lost his father at an early age and was raised by the local blacksmith (Van Ruler 2003:2). At 15 he started his theological studies at the University of Leiden. After graduation, he served as pastor in Vlijmen (1611-1617) and in his hometown Heusden (1617-1634). In 1612, Voetius married Deliana van Diest; they had 10 children. He preached eight times a week and worked tirelessly, bringing many Roman Catholics into the Reformed Church. Apart from his ministerial duties, he was a scholar who habitually rose at four in the morning to read ancient literature, study philosophy, law, science, geography, theology and Semitic languages (Hebrew, Arabic and Syrian) (Jongeneel 1998:2). He learned to play the zither, the organ and the flute. In 1634 he accepted a call as lecturer to the newly established Illustrious School of Utrecht, which in 1636 officially became the University of Utrecht. Since 1641 Voetius served as rector of this university, which was growing in prominence and which Voetius changed into a true 'Academia Voetiana', that is, according to some of his adversaries, a seminaria ecclesia headed by 'abbot' Voetius (Van Rinsum \& Koops 2016:16). 'Papa Ultrajectinus' (in reference to his defence of the scholastic methods) was also a nickname that stuck. With the aid of his 'Voetian circle', consisting of bright colleagues like Hoornbeeck, Essenius, Amesius and Nethenus (Hofmeyr 2016:20) and his often controversial and ultra-orthodox Calvinistic views, he exerted a lasting influence not only on everyday life in Utrecht, but on Dutch culture at large. Simultaneously with his academic work, he also served as part time pastor in Utrecht and could regularly be found teaching catechism to the poor orphans of the city.

Voetius wrote prodigiously on a variety of philosophical and theological issues of his day. As the 'Defender of Reformed Orthodoxy' (Jongeneel 1998:3), he mostly wrote polemically books and tracts against Arminianism, Socinianism, the Catholic Church, Cartesian Philosophy, and on church-state relationships, church polity, Jewish and Islamic issues, practical theology, missiology, et cetera. Voetius regarded philosophy in the neo-scholastic, Aristotelian mould as espoused by medieval scholars like Thomas Aquinas, and even more so the Scottish philosopher, Duns Scotus (Hofmeyr 2016:44-45; 2018:76, in reference to Beck 2007) to be the handmaiden (logical framework, methodological approach) of the Reformed theology (see also Van Rinsum \& Koops 2016:10). The irony, however, is that he defended Reformed piety against rationalism by using a rational, scientific method (Aristotelian logic and metaphysics) (Brown 1995:15). But then, human reasoning (our rational faith) should eventually be subjected to the revelation and authority of the Bible, he stated (Beck 2007:515, quoted by Hofmeyr 2016:45).

At an old age, it was Voetius who was invited to preach on 16 November 1673 in the Utrecht Dom, the day Protestant services resumed after the year-long occupation by French Catholic troops of Utrecht and this ancient church building has been ended. On 01 November 1676, Voetius died at the age of 84 and was buried in the Catherijnekerk (today an important Catholic centre in the Netherlands) (Vanhaelen 2005:54ff.).

\section{Synod of Dordt (1618-1619)}

As representative of the circuit of Heusden, and still at the very young age of 29, Voetius attended and actively participated in the Synod of Dordt (1618-1619). This 'ecumenical' synod was convened to referee in the dispute within the Dutch Protestant Church between followers of Armenius and those of Gomarus. While still a student at Leiden, Voetius made his choice between the Armenian semi-Pelagian views (Remonstrants) supporting man's free will, and those of his mentor Gomarus (Contra-Remonstants) advocating the sovereignty of divine grace as espoused in the Calvinistic doctrines of Predestination and Election. An understanding of man's free will 'which subjects God to man, Creator to creation' is not acceptable, he wrote as student (Van Ruler 2003:3). Early on he was drawn into the divide; in his home town he had to fight a prolonged battle against the Armenian party who wanted to prevent his nomination as minister.

The Synod of Dordt reacted to the five points set out in the Remonstrant Declaration. The Synod particularly felt that the Remonstrants failed to uphold the sovereignty of God's grace in the work of salvation from sin. The Synod therefore formulated the Canons of Dordt, insisting on doing justice to the sovereignty of God's grace and the inability of a fallen person to add any credit to his or her salvation. However, it also holds on to the responsibility of each one to accept the offer of grace in faith. The Canons of Dordt affirmed that salvation is wholly by divine grace and not by human merit. It would not be correct to say, however, that the Canons of Dordt negated human responsibility or understood reprobation or rejection by God in a scholastic, metaphysical, and fatalistic or supra-lapsarian way. In this way, God would become the author of sin (Hoekema 1972:210). It did not reveal the rigid orthodoxy with which the Canons are commonly charged. Although the Canons could be criticised for its inability to escape scholastic tendencies and formulations, its authority and significance as Confession lies rather in the matter it wanted to confess - a Reformed viewpoint that Voetius accepted (Jonker 1995:38).

But how did Dordt connected the doctrine of Election (Predestination) with the need to embark on mission? The Canons expressed a deep concern for the salvation of humans, 'that men, through election and believe on Jesus Christ, be reconciled with God'. This process of reconciliation of humans with God was perceived as the work of God. From the beginning in God's pretemporal decree to its consummation in eternity, it is the fruit of God's sovereign grace - grace alone - and not based in human merit. The Canons' focus could thus be described as missio Dei [God's mission]: God's redemption of the whole world through the work of Jesus Christ, applied to the hearts of people 
by the Holy Spirit (Hoekema 1972:211). But God incorporates his church as agent in this mission to the world:

Moreover, it is the promise of the gospel that whoever believes in Christ crucified shall not perish but have eternal life. This promise, together with the command to repent and believe, ought to be announced and declared without differentiation or discrimination to all nations and people, to whom God in his good pleasure sends the gospel. (Canons of Dordt II, 5)

Mission is founded in the elective love of God:

But this is how God showed his love: he sent his only begotten Son into the world, so that whoever believes in him should not perish but have eternal life. (1 Jn 4:9; Jn 3:16; Canons of Dordt I, 2)

The foundational Bible text to support the conviction that God brings people to faith through human agency, is Romans 10:12-15:

In order that people may be brought to faith, God mercifully sends messengers of this very joyful message to the people and at the time he wills. By this ministry people are called to repentance and faith in Christ crucified. For 'how shall they believe in him of whom they have not heard? And how shall they hear without someone preaching? And how shall they preach unless they have been sent?' (Rm 10:14-15; Canons of Dordt I, 3)

Although the efficacy of the death of Christ extends only to the elect, it 'is of infinite value and worth, more than sufficient to atone for the sins of the whole world' (Canons of Dordt II, 3). It must be proclaimed indiscriminately to all, for God earnestly desires the salvation of all (Canons of Dordt III, 8). Those who belong to God's elect will respond in faith and obedience. It is reassuring to the task of mission that its purpose of gathering the elect will certainly be fulfilled. It is not for us to discriminate or to judge those to whom the gospel is not proclaimed or those who do not answer in faith.

The Synod of Dordt did not only produce the Canons, which laid the foundation for mission, but also engaged in discussions and put forward decisions that had implications for the Dutch churches and their practical missionary involvement. Three issues were discussed: (1) the state's role in preventing the expansion of Jewish faith and the eventual conversion of Jews; (2) means (including ministers and permission for the use of the Malay language) for expanding mission work in an orderly way to East-India and other foreign countries; and (3) the baptism of the children of 'heathen' who have been adopted by Christian parents as well as children born from extra marital relations between Dutch and East-Indian persons (Van Andel 1912:16). Voetius played a major role in the preparation of recommendations regarding these matters, especially the baptism issue which was discussed for three consecutive days. The Synod was hesitant: baptism should not be forced onto children; they could only be baptised after appropriate catechetical instruction and public profession of faith (Jongeneel 1991b:48); and once baptised, they would be set free from slavery (Smit 1995:49). In the Church Order accepted by Dordt, provision was made in Article VII for the sending of ministers to other areas or the gathering of persecuted congregations ('hier oft daer te predicken inde Gemeente onder 't Cruyce/ofte andersins om Kerckê te vergaderen'). The sending of missionaries increased significantly in the years immediately following Dordt (Knegt 2018:267). Although the terms missio or missiones were absent from the vocabulary of Dordt (it was only used in later documents of Voetius, for instance his Politica Ecclesiastica of 1669-1671 (Van Andel 1912:20), the Synod of Dordt was the first National Synod that reflected extensively on mission. Only the church is mandated to do mission work and not the state or other institutions or individuals. Mission is the growth or planting of the same church that is sent, and the planted church should grow in unity with the sending church, but not in dependence of or dominated by it (Smit 1995:52-53). Voetius has had influence on the outcomes of the Synod of Dordt, but then Dordt also had a profound influence on Voetius' missiology and church polity (Brown 1995:13).

\section{Dutch Second Reformation}

Voetius visited England in 1636 and was inspired by Puritan models, which influenced his extensive contribution as leading academic shaping the Dutch Second Reformation (Nadere Reformatie; also called the Further Reformation). This movement called for 'a Christian purification of society through the private and public practice of piety' (Van Ruler 2003:3). The goal of the Dutch Second Reformation was to apply the orthodoxy of the initial Reformation more intimately in personal lives, in the church's worship and in the entire society.

During his years of teaching at Utrecht, Voetius taught some very promising young theologians such as Hoornbeeck, Essenius and Nethenus. Together with them and various others, he established Utrecht as the academic hub of the Dutch Second Reformation and especially of the early or first classical phase of this theological movement (Hofmeyr 2016:26, 42). The Voetian circle in Utrecht were generally regarded as being a Calvinist orthodox group who rejected liberal tendencies in theology as well as Cartesianism in science and philosophy, and who guided society towards a more sanctified lifestyle. (Hofmeyr 2016:43).

Voetius, for instance preached in favour of the strict observation of the Sabbath, he forbade such practices as visiting public houses, playing with the dice, the wearing of luxurious clothes, dancing, drunkenness, revelry, smoking and the wearing of wigs - he thus promoted a kind of legalistic ethic! Voetius offered his fellow-citizens and students a practical guidance in the exercise of prayer and contemplation (Van Ruler 2003:5) and he expressed his concern for the lack of missionary enthusiasm (Hofmeyr 1989:27). Nevertheless, such 'precisianism' (noticeable preciseness in the desire to serve God fully, according to his will - they were nicknamed 'de fijne' or 'fine ones') and consequential focus on the practice of piety (praxis pietatis; praktijk der godsaligheid) was not a goal in itself. Rather, it was deemed necessary to counteract the alleged worldliness 
(spiritual and ethical sterility) then prevailing in a rapidly expanding Protestant church and the flourishing Dutch society. It was also necessary as a means of sustaining and developing individual faith and conduct against spiritual shallowness. It strived for a theocratic society. It was the Dutch counterpart of Anglo-Saxon Puritanism and even the experiential spirituality of the German Pietism (Knegt 2018:264).

The Dutch Second Reformation also led to some unfortunate developments. Although a few Second Reformation leaders condoned separatism, numerous conventicles ('gezelschappen') in the German pietistic fashion for the nourishing of spiritual life were formed. Regarding the assurance of faith (election), the Second Reformation not only emphasised the promises of God and the witness of the Spirit, but also increasingly accentuated the syllogisms (proof of election in practical conduct of life, or 'bevindelijkheid'). A transition from the syllogismus practicus in the classical period to the syllogismus mysticus [mystical experiences as proof of being elected or converted], was made in the later period (Beeke 2009:n.p.).

\section{Core concepts in Voetius' missiology}

The commencement of Protestant mission work through the Dutch commerce with the East, and the founding of Roman Catholic mission orders and rapid expansion of their missions, convinced Voetius of the necessity to formulate a Protestant theology of mission. Voetius can be considered the first to develop a comprehensive, contextual and comparative Protestant missiology (Jongeneel 1998:3). Voetius' missiology, however, remained relatively unknown for two centuries or more until under the influence of Abraham Kuyper, it has been 'rediscovered' and 'dusted' by the Synod of Middelburg in 1896 (Historish Document 1940). In 1910, D. Pol translated Voetius' De plantatione ecclesiarum as Tractaat over de planting en de planters van kerken and H.A. van Andel systemised Voetius' missiology in his dissertation, De zendingsleer van Gisbertus Voetius (1912). Both these books made the missiology of Voetius, which was mostly written in Latin, accessible (the Latin references in this article are from Van Andel's book of which large parts are in Latin). This article also depends on these two books as 'primary sources.

Voetius used different names for the notion of mission, like the "calling of heathen" (vocatio gentium) or the 'planting of churches' (platatio ecclesiae aut ecclesiarum), but he eventually called it missiology (missiones in Latin, or zendingsleer in Dutch). He understood the term mission in a very broad way - almost all actions taken by the church could be considered part of its mission. Primarily, mission would involve 'the establishment of the ministry of the Word by the instituted church', and secondarily it meant 'being sent' to the 'pagan' world (Jongeneel 1991b:52). Voetius' theology of mission is to be found in various publications throughout his career; it also forms an integral part of his writings on ecclesiology (Van Andel 1912:27). Van Andel tabulated all the sources to which Voetius referred in his reflection on mission, including some prominent Roman Catholic scholars (Jongeneel 1991b:53-54; Van Andel 1912:37ff.). Voetius' own theology was, however, moulded by Calvin's doctrine of Predestination. An important Reformed interlocker has been Voetius' one-time student and later 'beloved' colleague, Johannes Hoornbeeck (Hofmeyr 2016:20; Van Andel 1912:59; Voetius 1910:50).

In De plantatione ecclesiarum, Voetius outlines and structures his theology by asking the following questions: Who sends? To whom is one sent? Why is one sent? Who and what kind of people are sent? In which way, and by which method, are people sent? What do missionaries have to give attention to? (Voetius 1910:39ff.).

To Voetius, mission could only be founded in God, in God's decision and God's will (hidden, predestined and revealed will of God in the Old and New Testament), as well as God's fulfilled and still to be fulfilled promise - all bearing down to God's election, the calling (vocatio), conversion and salvation (conversio et salus) of the elect (electorum) from all nations (universitas gentium). Mission work is the means through which God's goal of saving the elect is reached. These concepts were directly taken from the Canons of Dordt (I, 7, III and IV, 8) (Van Andel 1912:63). The mandate for mission and the fulfilment thereof lies in Matthew 28:19; only partially fulfilled in the extraordinary apostolic era, but to be continued by the church in the ordinary cause of history (Van Andel 1912:69).

The primary, effective agent or ultimate cause of mission is God alone. But God incorporates (calls and sends) humans, particularly his church, as organs in proclaiming his Word to the elect. In this regard, and unlike Catholic teaching, calling and sending (vocatio and missio) are considered synonyms (Van Andel 1912:75). To be called as a minister would simultaneously mean to be sent as missionary. Apart from the minister of the Word in an institutionalised church, no separate office of 'missionary' could exist. (Jongeneel 1991b:71; Van Andel 1912:121). The secondary agent of mission would therefore be the church, mandated by God, and the minister officially called or sent by the church. By church, Voetius would primarily understand the local congregation (with its own consistory - see Acts 13) but in serving the well-being of the work, he also made provision for mission cooperation within circuits (presbyteries) and synods (Van Andel 1912:79; Voetius 1910:19). Private persons, not sent by the church, could not be legitimate agents of mission. Voetius used Romans 10:15 as basis for this (Voetius 1910:40). In thinking from an emphasis on the church as an official, legal institution, not much attention was given to the Reformed notion of the priesthood of all believers or the calling of each Christian to be a witness and to give witness. Individual members could, however, only do preparatory or supporting work for the proper mission of planting churches. Voetius was adamant that no mission organisation, no business companies (societates mercatorum), 
not the state (prinses or magistrates), nor bishops or Roman Catholic orders have any legitimate claim to plant churches. In a typically scholastic way, Voetius gave historical proofs to dispute the infallible mandate for mission of Roman Bishops (Voetius 1910:26-38). State organs or companies like the VOC could merely assist and create space for the church, for instance by carrying ministers on their boats to execute their sole mandate for mission work in colonised areas (Van Andel 1912:93). Apart from officially mandated ministers of the Word, the practical need in East India required that adjutores or assistant spiritual workers or missionary preachers, medical staff, teachers, catechists and 'comforters of the sick' (ziekentroosters in Dutch) also be sent by the church. They could not officially plant churches, but only serve to prepare the soil for official church planting by ministers. Ziekentroosters could baptise coverts, but not administer the Lord's Supper, which was to be the work of an official minister once a church has been planted. Depending on the context of the mission field, these adjutores need not be academically as qualified as official ministers. Voetius, however, stressed the importance of quality academic training - especially education for missions in all institutions where ministers are trained. The mission field is not the place to send 'theological misfits'; it rather demands from ministers as well as adjutores singular gifts, exceptional learning and wisdom, piety and pastoral skills (Jongeneel 1991b:69).

Voetius dedicated a large volume of literature to what he called the objects of the missionary enterprise. Mission is aimed at a wide variety of people who had been outside the true church (a vera ecclesia alieni), including non-believers, heretics and schismatics. He meticulously subdivided the objects of mission in different categories (Voetius 1910:50-53). He wrote much on the three so-called false religions: de Judaismo, de Gentilismo and de Muhammedismo. In approaching these faiths, a comprehensive knowledge of their teachings is required in order to refute them with appropriate (philosophical) methods, even before the Word could be proclaimed to and accepted by them (Van Andel 1912:132; Visser 2003:264). Missiology should thus be more than just religion or religious studies; religions had to be studied in order to convert adherents of those religions. In this sense, his missiology could be described as contextual, a missiology developed in context, and in terms of the customs of his time, intensely polemical (Jongeneel 1991b:51).

The one facet of Voetius' missiology that would have the greatest impact on future scholars of missiology, also in the 20th century South Africa, was his exposition of the threefold goal of mission. By discussing the goal of mission just after he has reflected on the objects of mission, Voetius underscores the vast difference between the reality and the changes that mission ought to bring. Mission is therefore of absolute importance. Voetius originally mentioned seven goals, including the regathering of persecuted churches, the reformation of deformed churches, the reunification of separated churches, et cetera (Voetius 1910:54-55). He eventually distilled it into three main goals in progressive order: (1) the calling, conversion and salvation of those elected (collectio et salus electorum) from all peoples (universitas Gentium), (2) the planting of the church (collectio et constitution ecclesiae aut ecclesiarum), and (3) all to the glory of God's grace (gloria et manfestatio gratiae divinae).

Regarding conversion, Voetius developed a theologia elenctica, referring particularly to a rational or scholastic disproving, refuting and exposing of the (false) beliefs of the people to be reached (Jongeneel 1991b:52). Conversion is needed before the planting of churches can follow. Conversion must firstly be visible and the converted be recognised as believers - the emphasis should be on confession and conduct of life (doctrina et mores) - before it is possible to move to the next step, namely church planting, which brings about communion with Christ and eternal salvation. Conversion, as praeparatio plantationis, would normally include four steps: (1) by persuasion, unbelievers would become hearers of the Word, (2) by accepting instruction in basic truths, they become catechumens, (3) by breaking with sin and growing in their understanding of grace and salvation, they become suitable to (4) finally, profess their faith, receive baptism and participate in the Lord's Supper as full members of the church (Jongeneel 1991b:65; Voetius 1910:6-7). This prolonged process then leads to the higher goal, the planting of a local church. Planting as term, stems from 1 Corinthians 3:6-7. It implies the first gathering of the converted into a fellowship (church), which Voetius considered an extremely important phase of the work (Voetius 1910:6-7).

Voetius, the 'father' of the Reformed church polity and author of Politica ecclesiatica, would naturally put much value on the church, especially the local congregation as legally constituted institution (Van Andel 1912:149). The newly constituted church, as a bond or fellowship that voluntarily developed between local believers (not through coercion or merely the presence of a priest), constitutes the end of mission. The sending church then has no authority over the planted church anymore. Its church order or form cannot be prescribed by the planting church and the new relationship should be coordinated one, voluntarily (Voetius 1910:20-21).

As Voetius started his reflection on missiology by laying its foundation and primary cause in God, he completed the circle by stating the glory of God as the final goal. For Voetius the glorification of God would lay in the salvation of sinners, the gathering of the elect, in the expression and fulfilment of God's free and sovereign grace. In his missiology, Voetius remained silent about the reprobation and hardening of hearts, or the justification of God's wrath upon those who are lost; he only spoke of election and salvation, and the manifestation of the glory of God's grace (Jongeneel 1991b:68; Van Andel 1912:150).

The means by which mission should be done, are firstly and foremost the proclamation of God's Word. Again, Romans 10:13-15 served as anchor text. Knowledge of philosophy (Goudriaan 2006:29ff.) and medicine, providing education, 
making use of the support of the state and other institutions could serve as supplementary to the proclamation of the Word. In terms of the role of the state, Voetius chose a midway between Roman Catholicism who tolerated no religious freedom, and the Libertinists, Remonstrants and others who advocated no restraint on religious freedom. Voetius upheld the notion of freedom of religious conscience, but that does not mean freedom of religious expression. The state has a duty to protect the community from idolatry and false worship and create space for the promotion of the kingdom of Christ (see Belgic Confession, Article 36). But the right and responsibility to evangelise and do mission work only belongs to the church (Jongeneel 1991b:50). Voetius expanded on different methods of bringing the different categories of non-believers and people of other faiths to conversion. Voetius was hesitant to use baptism or the Lord's Supper as a means of coercing people into conversion and church planting. He was adverse to the Roman Catholic's practice of using the sacraments as a mechanical means of infusing grace into persons, ex opere operato, and thus also automatically including them into the covenant. That explains his hesitancy at the Synod of Dordt to summarily allow the baptism of the children of the heathen.

\section{Influence on South Africa Voetius' general influence on the South African cultural and spiritual landscape}

Voetius' vast influence on the church and society in South Africa could be traced in various publications on a wide variety of subjects. His pioneer work on Reformed church polity, especially his Politica ecclesiastica (Smit 2018:2), which has been applied by Dutch scholars like H. Bouwman, is often quoted in the South African reflections on church polity. It is well known that Voetius himself, but especially his grandson, the jurist Johannes Voet with whom the senior Voetius maintained close contact, even made a huge impact on the Roman-Dutch Law inherited and applied in Southern Africa for centuries (Erasmus 2016:n.p.; Kerr 2012:2).

But Voetius' influence on South Africa stretched even further back into history, albeit an indirect influence. In 1652, during the heydays of the Dutch Golden Age of the 17th century, the VOC establish a Dutch settlement in what was then called 'Cape of Good Hope' (Southern tip of Africa), as a halfway station supplying fresh produce to the ships traveling to the East. With this Dutch settlement at the Cape, the Dutch Reformed version of faith was planted in African soil, to take root and further on spread deep into Africa as the (Dutch) Reformed family of churches (Van der Watt \& Odendaal 2017). The type of church that was established in South Africa resembled that of the mother church in the Netherlands, characterised by the spirituality of the 17th century Dutch Second Reformation. The characteristics of this church in South Africa would be on adhering to the three Confessions of Unison (Belgic Confession, Heidelberg Catechism and Canons of Dordt) and applying the Calvinist teaching to the everyday life of individuals and communities. The Dutch
Reformed Church in South Africa developed a piety that strived to be doctrinally sound, but also had to be experiential. In this regard, Hofmeyr mentions Voetius' popular publication on practical piety, De practijcke ofte oefeninge der Godtsaligheyd (Utrecht 1686), which was widely read among Dutch descendants in South Africa in the 18th and 19th centuries (Hofmeyr 1989:63). Assurance of faith (certainty of being elected) should find experiential prove in a life of repentance and conversion, holiness and renewal, and obedience to the biblical prescriptions. This Calvinistic piety would thus characterise the Afrikaner's (the descendants of the Dutch settlers) 'puritan' culture and their understanding of their purpose and mission in Africa as a chosen race. The first people who deliberately ventured into bringing the gospel to the indigenous population, were the comforters of the sick (Zieketroosters) and Dutch missionaries to Southern Africa. They were mostly lowly skilled workers who stemmed from the spiritual orbit of the Dutch Second Reformation. An overt emphasis on conversion, holiness, even mysticism and a conventicle spirit have been well documented. It peaked in the mission endeavours of individual ministers such as Helperus Ritzema van Lier and M.C. Vos and the influential mission supporter, the widow Machteld Smit of the late 18th century (Hofmeyr 1989:53ff.; Schoeman 1997:123ff.; 2005).

\section{Voetius' influence on missiology in the Dutch Reformed Church}

Voetius's missiology became known to South African scholars through Van Andel's book, De zendingsleer van Gisbertus Voetius (1912), but the first deliberate reflections on Voetius' missiology in South African missiological publications could be ascribed to J.H. Bavinck, who introduced Voetius to South African scholars. Bavinck's missiology was profoundly influenced by Voetius. Like Voetius, Bavinck founded his missiology theocentric (although less so in the doctrine of election than is the case with Voetius); his missiology is ecclessiocentric (see also the influence of the Middelburg 1896 Synod's emphasis on the church's sole mandate for mission, inevitably leading to the planting of a church as goal). Bavinck extensively explained Voetius' threefold goal of mission: he defined mission as a comprehensive proclamation of the Word and he gave much attention to a theologia elencta (Visser 2003:90ff.). Since the publication of Bavinck's Inleiding in de Zendingswetenschap (1954), it became a prescribed handbook to theological students in most South African Reformed Faculties of Theology. Bavinck, sponsored by the Theological Fund of the International Missionary Council, visited South Africa three times, viz. in 1952 to acquaint himself of the missionary situation; in 1953 to mainly taught at the University of Potchefstroom Theological Faculty; and in 1963 he crisscrossed the country, gave several lectures and wrote articles in which he, in a softly spoken but also unequivocal way, pointed to the indefensibility of the church's theological support of the racial politics of Apartheid (Visser 2003:51, 74). Later on Johannes Verkuyl's Inleiding in de nieuwere ZendingsWetenschap (1975) and Jan Jongeneel's two volumes (1986 and 1991a), in which they reflected on Voetius's missiological principles, were also studied in South Africa. 
Johannes du Plessis, the early 20th century groundbreaking missiologist in South Africa, was not directly influenced by Voetius. He rather sought linkage with the German volkskristianiserung theology of scholars such as Gustav Warneck, but he also found himself at home in the evangelical (Dutch Second Reformation) stream represented by ministers Van Lier and Vos (Bosch 1986:42ff.). G.B.A. Gerdener, who succeeded Du Plessis as Professor in Missiology at Stellenbosch University, followed in Du Plessis' footsteps. He took notice of Voetius in his popular publications, Reguit koers gehou (1951:80ff.) and Die Afrikaner en die sending (1959:29ff.). Clear traces of Voetius are also to be found in the Dutch Reformed Church's Mission Policy of 1935 (which was mainly written by Gerdener and influenced the Dutch Reformed Church's mission approach for decades to come), especially in the wording that the Dutch Reformed Church's Mission Policy is founded on Holy Scripture, specifically in the 'decision, promise and command of God'. It would, however, only be after the South African visits of J.H. Bavinck in the 1950s and 1960s that Dutch Reformed Church missiologist take specific interest in Voetius. In 1967, an officially celebrated 'Year of Mission' in the Dutch Reformed Church in South Africa, two important handbooks on missiology appeared. The first was the book by H.D.A. du Toit, Professor of Missiology at Pretoria University, Die kerstening van die Bantoe (1967), in which he used Voetius' threefold goal of mission and his questions to whom?, by whom?, et cetera for structuring his mission theology. He especially referred to Voetius' views on church planting and the planted church's relation to the one who planted it (Du Toit 1967:40ff.). He also referred to Voetius' allowance for a synod to do mission work as basis for the Dutch Reformed Church's practice of mission done by synods or circuits, and not only local congregations (Du Toit 1967:53). In the second book, also published in 1967, W.J. van der Merwe's Gesante om Christus wil, the author (Professor of Missiology at Stellebosh) clearly made much use of Voetius' missiology. He founded mission in the essence of the triune God (p. 29); he extensively explained Voetius' three goals of mission (p. 32ff.); regarding church planting he refers to Middelburg 1896 who built on Voetius' understanding of the independence of the planted church (p. 39ff.) and how sad it is that the Dutch Reformed Church in South Africa, in its mission practice regarding the planting of domestic, independent young churches, did not follow the practical teaching of Voetius in this regard (pp. 48-49), but rather that of the German indigenous (and separate) Volkskirchen (pp. 55-56); and he also reflected on the office of a missionary as being, according to Voetius, nothing else but a minister of the Word (p. 71). In his DTh thesis in 1974, J.H. Smit (Missiology Professor at Bloemfontein) pleaded for the merging of the office of minister and missionary ending the longstanding practice of differentiating between 'ministers' and 'reverends' (eerwaardes), basing his arguments on Voetius. In Kritzinger, Meiring and Saayman's (all Professors in Missiology) book, On being witnesses (1994), they also used Voetius' threefold goal of mission for the structure of the first chapter on mission theology (pp. 1-39). They gave a beautiful definition of conversion as the goal of mission, but in which the sounds of Dordt 1618-1619 and Voetius are reverberating: 'Conversion is contextual; it is based on God's allencompassing love; it is a joyful invitation to communion with Jesus and his followers; and it is a call to service' (p. 34). In David Bosch's work, Transforming mission (1991), he refers to the crucial historical importance of Voetius as leading figure in the Dutch Second Reformation and his influence on missiological reflections of our day (pp. 256-257).

The abovementioned examples confirm that, in terms of the Reformed tradition, Voetius could be considered the major influence on the development of the South African Dutch Reformed Church's theology of mission in the second part of 20th century. However, this does not imply that influences from other resorts, for example the German, Anglo-Saxon and even the African context itself, were not also absorbed into the Dutch Reformed Church in South Africa.

\section{In conversation with Voetius from a current South African missional perspective}

Under the influence of David Bosch's Transforming mission (1991), as well as the works of Lesslie Newbigin, for instance his book, The gospel in a pluralist society (1989), but more specifically after the appearance of Darrel L. Guder's book, Missional church (1989), a new missional discourse dawned in the Dutch Reformed Church in South Africa. Deliberate programs aimed at the missional transformation of congregations eventually led to the 2013 Synod adopting an important framework document, The missional nature and calling of the Dutch Reformed Church. (Nelus Niemandt, currently Professor in Missiology at Pretoria University and then moderator of the Dutch Reformed Church in South Africa, was mostly responsible for its formulation). This new development would clearly stand in continuity with the Reformed missiology that prevailed in the Dutch Reformed Church in South Africa in the second half of the 20th century, but it would also entail a definite discontinuity with this tradition (Burger 2017:20-24). The document builds on what it calls 'new insights on our understanding of God', the missio Dei as well as 'sending' as core characteristic of the essence of the Triune God:

Mission is the salvific act of the Triune God - Father, Son and Holy Spirit - towards the world, through which He gathers to Himself a community by way of his Word and the Spirit from the entirety of humankind. (Dutch Reformed Church 2013:point 4.4)

Much is said on the nature and calling of the church, but mission is not defined ecclessiocentric anymore; stronger emphasis is rather put on service to the kingdom of God and on the church as the body of Christ, called to imitate Christ by incarnating into and selflessly (kenosis) serving the community; the church is invited to partake in God's mission to the world and it should by nature, essentially therefore be missional. Mission should also be radically contextual (therefore the importance of discernment) and comprehensive 
(a much broader understanding than in past eras). The context is understood as post-Christendom - the secularistic and pluralistic early 21st century Western culture.

From within this current missional discourse, it could be enriching to enter in a more conscious discussion with the roots of the Reformed missiology, especially that of Dordt 1618-1619 and Voetius. It will be interesting to discover that what is today often presented as 'new insights', can actually be traced back to someone like Voetius. But it will also be enriching to understand the necessary discontinuities with this tradition and what issues should indeed be regarded as 'new insights'. Two discussion points could serve as examples.

\section{A Trinitarian foundation of missiology, specifically focusing on election}

As has been said, the origin of a theocentric foundation for mission today, defined by the concept missio Dei, can also be traced back to Voetius. But in a post-colonial South African context, there is need for the radicalisation of this concept. According to Venter (2004:756), a specifically Trinitarian Renaissance is needed. He raised the question: 'How consistently trinitarian are we in theological and ecclesial practice? The trinitarian understanding of missio Dei?' (Venter 2004:757). If the very life of the triune God is characterised by love, communion, care and moving beyond the boundaries of the 'self'; then the church is called to participate in this movement of the 'affirmation of the other', mutuality and relationship. Mission, Venter writes (2004:758), is therefore extending an invitation to enter a specific new world, a Trinitarian space where the God of communion extends God's hospitability.

Regarding a Trinitarian point of departure, it could be helpful, surprising and even shocking to also revisit the doctrine of election - which is unfortunately largely absent in the current missional discourse in South Africa - and learn how it has been applied, deformed and even abused as theological justification in the South African colonial history of Apartheid and in the church's official mission policy of many decades. Election, the sovereign and free grace of God's love, is regarded to be the very heart of the Reformed tradition. But it has been dangerously misunderstood in many ways, in emphasising the 'proof of election' in signs of conversion and a precise practice of piety, even to the extent that it threatened to undermine the very nature of free grace (Brown 1995:17), or in claiming the Afrikaner people (volk) to be a chosen people, and therefore entitled to the exclusion of 'the others' or separateness. This has often been the case in the whole missionary enterprise, as explored in Richards Elphick's (2012) seminal book, The equality of believers.

Election should not be understood in terms of a speculative scholasticism pretending to explain predestination, election and reprobation rationally (Newbigin 1989:80ff.), but rather in the context of inexplicable comfort for even the most wretched, as doxology. In Willie Jonker's book, Uit vrye guns alleen, he argues that this doctrine should only function in a doxological context as praise, born in wonder and gratitude for God's free grace in Christ and through the Spirit (Jonker 1989:13ff.; 1994:138ff.; see also Van der Westhuizen 2018:7). In the lecture given at his retirement from his post at Stellenbosch University, and which he further elaborated on in the 2018 Warfield Lectures at Princeton, Dirkie Smit 'remembers' how in Apartheid's darkest days, Herman Bavinck's description of election (which has also been fully quoted by Willie Jonker as motto of his book, Uit vrye guns alleen) helped him, and others like Desmond Tutu, Allan Boesak, Russel Botman and Jaap Durand, to shape their theological approach. It made them realise that there is hope, even for the most wretched, and that this is precisely what motivates God's mission to the world in which the church is invited to partake. To quote Smit (2018):

'Both for unbelievers and believers,' Bavinck writes, 'the doctrine of election is a source of inexpressibly great comfort'. He is deliberately polemical. The claim of Pelagianism is precisely that election leads to anxiety and fear, to the very opposite of 'inexpressibly great comfort'. Bavinck continues, substantiating his surprising claim, 'If it (salvation, well-being, flourishing, our comfort) were based on justice and merit, all would be lost. But now that election operates according to grace, there is hope even for the most wretched.' This is his claim, for him the good news of God's free and gracious election. Now - suddenly, surprisingly - there is hope even for the most wretched ... 'To believe in and to confess election,' Bavinck proceeds, 'is to recognize even the most unworthy and degraded human being as a creature of God and an object of his eternal love.' (p. 3)

A revisiting of the doctrine of election, as it also featured in Voetius' missiology, is therefore important and urgent in the current missional discourse and in reflecting on the church's calling to seek and embody justice, reconciliation and unity in the South African context.

\section{A relevant theologia elenctica and a call to conversion}

A theologia elencta, (from the Greek elenchein, to disprove or refute) as advocated by Voetius and J.H. Bavinck, required extensive knowledge of the people to be reached, and therefore contextual discernment. But because of the way it has often been practised by the church (intensely polemical, even hostile), it acquired such a tainted past that it in fact disappeared from modern missiology, as is also the case in the current missional discourse in South Africa. The focus in the missional discourse is rather on the missional transformation of the church itself on being missional. The inescapable question of how and where to find a proper point of contact (connection) an appropriate approach in bringing the good news of salvation, of inviting non-believers and people of other faiths to believe in Christ Jesus - the how of evangelisation - should remain a core question in missiology. According to Visser (2003) it is:

particularly pressing now that the church everywhere finds itself confronted with syncretistic tendencies, and immersed in societies that are becoming ever more thoroughly secularised and at the same time increasingly multireligious. (p. 281) 
Evangelism therefore remains the heart of mission. According to Bosch's (2008) definition:

it consists in the proclamation of salvation in Christ to nonbelievers, in announcing forgiveness of sins, in calling people to repentance and faith in Christ, in inviting them to become living members of Christ's earthly community, and to begin a new life in the power of the Holy Spirit. (p. 9)

It should be done in 'humility' - the call to conversion should begin with the repentance of those who do the calling, who issue the invitation (Bosch 1991:414). It should, however, also be a witness in 'boldness', mandated and motivated by seeking the manifestation of the glory of God's grace through the salvation of the elect from all nations and the gathering of people into the body of Christ.

Voetius must be read within the historical context in which he lived and worked. In a continuous discussion with this exceptional Reformed scholar of the 17th century, the current missional discourse of the early 21st century may just be surprised to discover how much of Voetius' insights are still relevant and can even today be explored beneficially.

\section{Acknowledgements Competing interests}

The author declares that he has no financial or personal relationship(s) which may have inappropriately influenced him in writing this article.

\section{References}

Bavinck, J.H., 1954, Inleiding in de zendingswetenskap, Kok, Kampen.

Beck, A., 2007, Gisbertus Voetius (1589-1676): Sein Theologieverständnis und seine Gotteslehre, Unpublished Doctoral dissertation, Utrecht.

Beeke, J.R., 2009, 'The Dutch Second Reformation (“Nadere Reformatie”)', in W. à Brakel (ed.), The Christian's reasonable service, vol. 1, trans. B. Elshout, pp. Ixxxv-cxi, P.A. Morgan, Soli Deo Gloria Publications, viewed 01 December 2018, from http://www. abrakel.com/2009/11/dutch-second-reformation-dr-joel-r_06.html

Bosch, D.J., 1986, 'Johannes du Plessis: Grondlegger van die Sendingwetenskap in Suid-Afrika', in J. du Preez, C.M Pauw \& P. Robinson (reds.), Sendinggenade, sendingwetenskaplike opstelle aan Prof. W.J. van der Merwe, by geleentheid van sy tagtigste verjaarsdag, pp. 42-57, NG Sendinguitgewers, Bloemfontein.

Bosch, D.J., 1991, Transforming mission, paradigm shifts in theology of mission, Orbis Books, Maryknoll, NY.

Bosch, D.J., 2008, 'Evangelism: Theological currents and cross-currents today', in P.W. Chilcote \& L.C. Warner (eds.), The study of evangelism - Exploring a missional P.W. Chilcote \& L.C. Warner (eds.), The study of evar
practice of the church, Eerdmans, Grand Rapids.

Brown, E., 1995, 'Die Sinode van Dordtrecht en die eenheid van die kerk', in R.M. Britz \& S.A. Strauss (reds.), Dordt na 375 jaar 1619-1994, pp. 9-21, Pro Christo, Bloemfontein. (UV Teologiese studies 8).

Burger, C., 2017, 'Why we need the missional conversation in South Africa now', in C. Burger, F. Marais \& D. Mouton (eds.), Cultivating missional change - The future of missional churches and missional theology, pp. 20-34, BM-Biblecor, Wellington.

Du Toit, H.D.A., 1967, Die kerstening van die Bantoe, NG Kerkboekhandel, Pretoria.

Dutch Reformed Church, 2013, The missional nature and calling of the Dutch Reformed Church, viewed 01 January 2019, from http//ngkerk.org.za/wp/?s=the+missional +nature+and+calling+of+the+Dutch+Reformed+Church

Elphick, R., 2012, The equality of believers - Protestant missionaries and the racial politics of South Africa, University of Virginia Press, Charlottesville.

Erasmus, H.J., 2016, 'Natural law: Voet's criticism of De Groot' Fundamina vol. 22(1) viewed 18 January 2019, from http://www.scielo.org.za/scielo.php?script=sci arttext\&pid=S1021-545X2016000100003

Gerdener, G.B.A., 1951, Reguit koers gehou, NG Kerkuitgewers, Kaapstad.

Gerdener, G.B.A., 1959, Die Afrikaner en die sending, NG Kerkuitgewers, Kaapstad.

Goudriaan, A., 2006, Reformed orthodoxy and philosophy, 1625-1750, Gisbertus Voetius, Petrus van Mastricht and Anthonius Driessen, Brill, Leiden. (Brill's series in Church history, 26).

Guder, D.L. (ed.), 1989, Missional church - A vision for the sending of the church in North America, Eerdmans, Grand Rapids.
Historish document, Referaat van wijlen Professor Dr. A. Kuyper over zending, Uitgesproken op het Zendingcongress te Amsterdam op 28, 29 en 30 Januari 1890.... Hierbij zijn gevoegd besluiten van de Synode te Middelburg in 1896 gehouden ..., 1940, Bootsma, Utrecht.

Hoekema, A., 1972, 'The missionary focus of the Canons of Dordt', Calvin Theological Journal 7, 209-220.

Hofmeyr, J.W., 1989, Die Nederlandse Nadere Reformasie en sy invloed op twee kontinente, Unisa, Pretoria.

Hofmeyr, J.W., 2016, 'Johannes Hoornbeeck, a monumental 17th century Dutch theologian: Continuities in his thinking in doctrine and life', Acta Theologica 36(2), 19-48.

Hofmeyr, J.W., 2018, 'The 17th-century Johannes Hoornbeeck's views on mission, ecumenism and historical theology and its current relevance', Acta Theologica 38(1), 61-83. https://doi.org/10.18820/23099089/actat.v38i1.4

Jongeneel, J.A.B., 1986, Missiologie 1, Zendingsweteschap, Boekencentrum, Utrecht. Jongeneel, J.A.B., 1991a, Missiologie 11, Missionaire theology, Boekencentrum, Utrecht. Jongeneel, J.A.B., 1991b, 'The missiology of Gisbertus Voetius: The first comprehensive protestant theology of missions', Calvin Theological Journal 47-79.

Jongeneel, J.A.B., 1998, 'Voetius, Gisbertus [or Gijsbert Voet] (1589-1676) Dutch Reformed theologian and first Protestant to write a comprehensive theology of mission', in G.H, Anderson (ed.), Biographical Dictionary of Christian missions, New York: Macmillan Reference USA, viewed 28 November 2018, from http:// www.bu.edu/missiology/missionary-biography/t-u-v/voetius-gisbertus-gijsbertvoet-1589-1676/

Jonker, W.D., 1989, Uit vrye guns alleen, NG Kerk-Boekuitgewers, Pretoria.

Jonker, W.D., 1994, Bevrydende waarheid - Die karakter van die gereformeerde belydenis, Hugenote Uitgewers, Wellington.

Jonker, W.D., 1995, "n Eresuil vir Dordt - gedagtes oor die handhawing van die gereformeerde belydenis', in D. Britz \& S.A. Strauss (reds.), Dordt na 375 jaar 1619-1994, p. 39, Pro Christo, Bloemfontein. (UV Teologiese studies, 8).

Kerr, A.J., 2012, 'How a religious quarrel influenced Roman-Dutch Law', in The receptions and codification of systems of law in Southern Africa, viewed 21 January 2019, from https://romandutchlaw.wordpress.com/2011/08/13/how-areligious-quarrel-influenced-roman-dutch-law/

Knegt, C., 2018, 'That Christ be honored: The push for foreign missions in the seventeenth-century Reformed Church in the Netherlands', Puritan Reformed Journal 10(2), 263-277.

Kritzinger, J.J., Meiring, P.G.J. \& Saayman, W.A., 1994, On being witnesses, Orion Publishers, Halfway House, Johannesburg.

Newbigin, L., 1989, The gospel in a pluralist society, Eerdmans, Grand Rapids, MI.

Schoeman, K., 1997, Dogter van Sion, Machtelt Smit en die 18de-eeuse samelewing aan die Kaap 1749-1799, Human \& Rousseau, Kaapstad.

Schoeman, K., 2005, The early mission in South Africa; Die vroeë sending in SuidAfrika, Protea Book House, Pretoria.

Smit, D.J, 2017, 'Hope for even the most wretched?' On remembering the reformation retirement lecture, Dirk J. Smit, 11 October 2017, viewed 16 December 2018, from https://www.google.co.za/search?source=hp\&ei=VpVNXMXalqOBur4Pkp6xsAo\& $q=D J+S m i t+e l e c t i o n+t h e+m o s t+w r e t c h e d+\& b t n K$

Smit, J., 2018, 'The decline of reformed church polity in South Africa', In die Skriflig 52(3), a2309, viewed 11 December 2018, from https://doi.org/10.4102/ids. $52(3)$, a2309
v52i3.2309

Smit, J.H., 1974, Die amp van die sendingleraar in die jongere kerk: Met besondere verwysing na die jongere kerke uit die sending van die Nederduits Gereformeerde Kerke in Suid-Afrika, DTh,-tesis, Universiteit van Stellenbosch, Stellenbosch.

Smit, J.H., 1995, 'Die Sinode van Dordt en die sending', in R.M. Britz \& S.A. Strauss (reds.), Dordt na 375 jaar 1619-1994, bl. 45-55, Pro Christo, Bloemfontein. (UV Teologiese studies 8).

Van Andel, H.A., 1912, De zendingsleer van Gisbertus Voetius, Kok, Kampen.

Van der Merwe, W.J., 1967, Gesante om Christus wil, NG Kerkuitgewers, Kaapstad.

Van der Watt, G. \& Odendaal, M., 2017, A family of reformed churches in Africa Remarkable stories of God's grace, CLF Publishers, Wellington.

Van der Westhuizen, H., 2018, 'The Trinity in the Canons of Dordt?', In die Skriflig 52(2), a2338, viewed 18 November 2018, from https://doi.org/10.4102/ids.v52i2.2338

Van Rinsum, H. \& Koops, W., 2016, 'University of Utrecht 1636-1676: res ecclesia, res publica and ... res pecunia', History of Education 45(1), 1-17, viewed 11 December 2018, from http://dx.doi.org/10.1080/0046760X.2015.1066881

Van Ruler, H., 2003, 'Short biography of Gisbertus Voetius (1589-1676), in W. van Bunge, et al., The dictionary of seventeenth and eighteenth-century Dutch philosophers, 2 vol., Thoemmes Continuum, viewed 01 November 2018, from https://witsius. wordpress.com/2011/09/17/a-short-biography-of-gisbertus-voetius-1589-1676/

Vanhaelen, A., 2005, Utrecht's Transformations: Claiming the Dom through representation, iconoclasm and ritual, viewed 18 January 2019, from https:// www.mcgill.ca/ahcs/files/ahcs/dezeventiendeeeuw_vanhaelen.pdf

Venter, R, 2014, 'Trinity and mission: Challenges to a reformed witness in Africa today', Verbum et Ecclesia 25(2), 751-768. https://doi.org/10.4102/ve.v25i2.298

Verkuyl, J., 1975, Inleiding in de nieuwere zendingswetenshap, Kok, Kampen.

Visser, P.J., 2003, Heart for the gospel, heart for the world - The life and thought of a reformed pioneer missiologist Johan Herman Bavinck (1895-1964), Wipf \& Stock, Eugene, OR.

Voetius, G., 1910, De plantatione ecclesiarum: Tractaat over De planting en de planters van kerken, transl. D. Pol, Firma Bouwman \& Venema, Groningen. 